\title{
CHARACTERIZATION OF THE OCEAN-CONTINENT TRANSITION IN THE PARAÍBA BASIN AND NATAL PLATFORM REGION, NE BRAZIL
}

\author{
José Ricardo Magalhães, José Antonio Barbosa, \\ Jefferson Tavares C. Oliveira and Mário F. de Lima Filho
}

\begin{abstract}
Several studies have tried to address the evolution of the Atlantic conjugate margins, including Brazil and West Africa. However, past research advances has been hindered by a lack of data for the marginal region in the eastern portion of northeastern Brazil, extending from the Pernambuco Shear Zone to the Touros High. This situation has imposed serious limitations on the development of a regional view of the paleotectonic and paleogeographic evolution of the margin in this area and on correlations with regional counterparts in Africa. Here, we present an investigation using regional seismic and potential field data. The results show that this region represents a basement high forming a narrow platform with a thin sedimentary cover (0.8-2.5 km) and an abrupt shelf break, which created a large bypass zone towards the slope. The analysis of a deep seismic section revealed that thinned continental crust (transitional crust) occupies a narrow zone and that the continentaloceanic boundary (COB) is located approximately $100 \mathrm{~km}$ to the east of the present coastline. Geophysical modeling integrated with interpretation of the seismic data suggests that this region is characterized by an abrupt thinning of continental crust, with an accompanying sudden rise of the Moho. There are also indications for the existence of a zone of extremely thinned continental crust, which was interpreted as proto-oceanic crust. Our findings suggest that the study area shows strong similarities to non-volcanic rifted margins.
\end{abstract}

Keywords: Paraíba and Natal Platform Basins, continental-oceanic transition, northeastern Brazilian continental margin, Atlantic rift.

RESUMO. Vários trabalhos têm tentado abordar a evolução das margens conjugadas do Atlântico, incluindo o nordeste do Brasil e 0 oeste da África. Entretanto, 0 avanço de pesquisas anteriores tem sido dificultado em razão da falta de dados na região marginal da porção oriental do nordeste do Brasil, a área entre a Zona de Cisalhamento de Pernambuco e o Alto de Touros. Este fato tem imposto limitações ao desenvolvimento de modelos regionais sobre a evolução paleotectônica e paleogeográfica desta região, assim como na correlação com sua contraparte na África. Aqui é apresentada uma investigação realizada com base em dados sísmicos e de métodos potenciais regionais. Os resultados mostraram que esta região representa um alto do embasamento que forma uma plataforma estreita com uma cobertura sedimentar pouco espessa (0,8-2,5 km) e uma quebra abrupta da plataforma, o que criou uma grande zona de bypass através do talude. A análise de uma seção sísmica profunda revelou que a crosta continental afinada (crosta transicional) representa uma estreita zona, e que o limite crosta continental-oceânica (COB) está localizado a aproximadamente $100 \mathrm{~km}$ a leste da atual linha de costa. A modelagem geofísica, integrada com a interpretação sísmica, indica que esta região é caracterizada por um afinamento abrupto da crosta continental, com a consequente ascensão súbita da Moho. Também há evidências da existência de uma zona de crosta continental extremamente afinada, a qual foi interpretada como crosta proto-oceânica. Estes novos dados demonstram que esta área apresenta fortes similaridades com margens rifteadas não vulcânicas.

Palavras-chave: bacias da Paraíba e da Plataforma de Natal, transição crosta continental-oceânica, margem continental do nordeste Brasileiro, rifte Atlântico.

Universidade Federal de Pernambuco, CTG-UFPE, LAGESE, Departamento de Geologia, Avenida Acadêmico Hélio Ramos s/n, Cidade Universitária, 50740-530 Recife, PE, Brazil. Phone: +55(81) 2126-7934/2126-8240; Fax: +55(81) 2126-8234 - E-mails: j.ricardo_magalhaes@hotmail.com; jose.antoniob@ufpe.br; jeffersonfisico@hotmail.com; mfl|@ufpe.br 


\section{INTRODUCTION}

There is a large body of research on the conjugate evolution of the Brazilian and African margins. The majority of this work has focused on the Angola, Congo, and Gabon Basins (Africa), and their counterparts: Santos, Campos, Recôncavo, SergipeAlagoas, and Pernambuco Basins (Brazil) (Meyers et al., 1996; Karner \& Driscoll, 1999; Blaich et al., 2008, 2010, 2011; Aslanian et al., 2009; Lentini et al., 2010). However, none of these studies did address the characteristics of the Brazilian continental margin region located between the Pernambuco Shear Zone (PESZ) and the Touros High (Fig. 1).

The focus areas of this study are the Paraíba Basin and the Natal Platform region (zone of the continental shelf offshore Natal, where the continental basement forms a ramp diping slightly towards the shelf break) (Barbosa \& Lima Filho, 2006; Barbosa et al., 2008). In the context of this research, we adopted the proposition that the study region represents a set of basins separated from the Pernambuco Basin, which is located between the Maragogi High and the PESZ (Barbosa \& Lima Filho, 2006) (Figs. 2, 3 , and 4). Considering its tectono-sedimentary features, it is important to treat this region as a distinct crustal segment, which is in contrast to the older view that combined all basins along the eastern border of the Borborema Province (BP) into a single zone, commonly named Pernambuco-Paraíba Basin.

Because of its unique characteristics compared to the neighboring marginal basins, Lima Filho \& Barbosa (2010) named the study area the "Exception Zone" (EZ) of northeastern Brazil (Fig. 1). This region represents the eastern portion of the BP, formed by Precambrian terrains and two main continental-sized shear zones: the PESZ and the Patos Shear Zone (PASZ) (Vauchez et al., 1995; Neves \& Mariano, 1999) (Figs. 2, 3, and 4). These two large shear zones border the Transversal Zone (ZTN), which forms the nucleus of the BP (Santos \& Medeiros, 1999; Van Schmus et al., 2003) (Figs. 1 to 4).

The main reason for the general lack of knowledge about this area is likely due to a dearth of geological/geophysical data, including onshore and offshore wells, as well as detailed geophysical surveys, including deep seismic surveys. This situation is chiefly caused by the interpretation of the area as having a low petroleum potential, which was proposed during the pioneer times of exploration along the Brazilian margin. Only one stratigraphic well was drilled along the coastal zone in the abovementioned region, and none in the offshore region of the study area. The only publicly available seismic data in the Brazilian National Exploration and Production Repository (BDEP), which is maintained by the Brazilian National Agency of Petroleum, Natural Gas and Biofuels (Agência Nacional do Petróleo, Gás Natural e Bio- combustíveis - ANP), consist of a set of about 30 2D seismic surveys produced in the late 1970s, whose quality is very poor (Barbosa et al., 2008). In addition, a set of deep seismic surveys is available, which were acquired by the Brazilian Navy for the exploration of the Brazilian Platform (LEPLAC Program). Figure 1 shows the two conjugate margins aligned for comparison: the eastern margin of northeast Brazil and its West African counterpart. Based on what is known about both margins, there appears to exist a better symmetry in the conjugate margins in Areas I and III, both in terms of continental extension and tectono-sedimentary characteristics, than in the conjugate margins of Area II (Brito Neves et al., 2002).

Several studies have addressed questions concerning the geological and geophysical characteristics of the eastern portion of the NE Brazilian margin, including its evolution and relationship with the opening of the South Atlantic (Fainstein \& Milliman, 1979; Rand \& Mabesoone, 1982; Reyment \& Dingle, 1986; Guiraud \& Maurin, 1992; Matos, 1992, 1999; Brito Neves et al., 2002; Barbosa \& Lima Filho, 2006; Barbosa et al., 2008). Fainstein \& Miliman (1979) were the first to suggest that the region between the two plateaus represents an area with a narrow platform and an abrupt shelf break, in contrast to neighboring basins such as the Potiguar Basin to the north and the Pernambuco and Sergipe-Alagoas Basins to the south (Fig. 1). In fact, the study region remains a regional basement high between the Brazilian equatorial (transforming branch) margin and the southeastern (extensional branch) margin along the Brazilian Atlantic Platform. Studies concerned with the asymmetries found between the conjugate northeastern Brazil and West African marginal basins suggested a variety of mechanisms to explain these asymmetries: pre-existence of weakness zones, crustal faulting and stretching processes during break-up, and asymmetric extension caused by the differential influence of a hotspot that possibly affected this portion of the Atlantic rift during the Albian (Rand \& Mabesoone, 1982; Matos, 1992; Turner, 1995; Meyers et al., 1996; Karner \& Driscoll, 1999; Matos, 1999; Brito Neves et al., 2002).

Recent studies have attempted to determine the main tectonosedimentary characteristics of the region. Based on their analyses of 2D seismic lines, Lima Filho \& Barbosa (2010) proposed that the Recife-Natal marginal zone evolved as a cold and thick slice of the eastern BP border, contrary to its counterpart in Africa, the Douala and Niger Delta Basins, which exhibit a more stretched continental crust and a thicker sedimentary column (Fig. 1). The authors argued that the Pernambuco Plateau (Fig. 1) was formed during the last phase of rift propagation across the South Atlantic. The rift advanced from south to north to establish a connection 


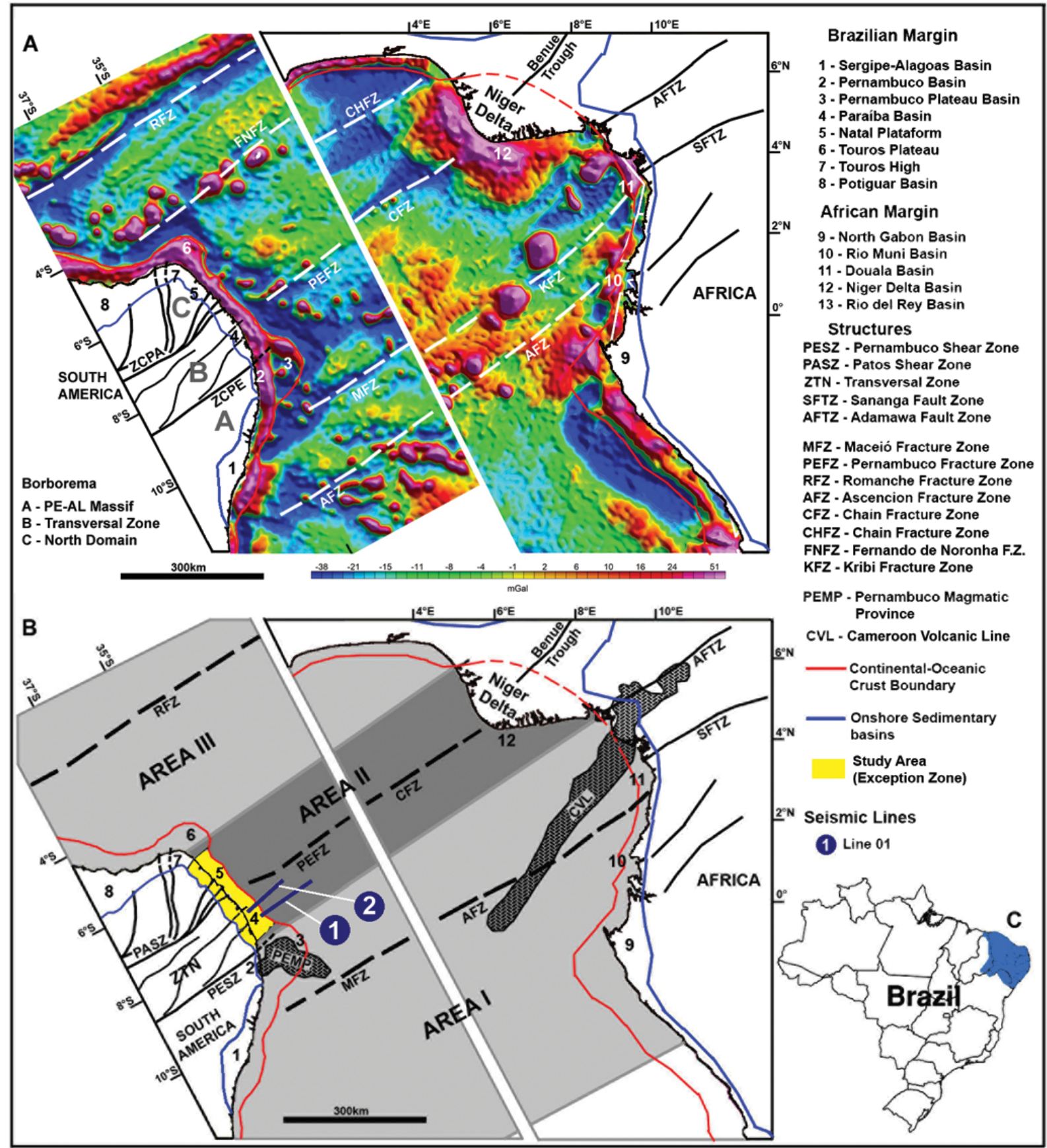

Figure 1 - Comparison of structures and geometry of northeast Brazil and its African counterpart. A) Free-air gravity anomaly map (from Smith \& Sandwell, 1997; Sandwell \& Smith, 2009); B) Schematic margin correlations, showing three main zones. Area Il presents major conjugate margins asymmetries with regard to structural style and sedimentary fill; C) Location of the Borborema Province (BP) (blue area). The two maps are juxtaposed for comparison purposes and are not a reconstruction of the drift of the plates. The yellow zone represents the study area, named "Exception Zone", along the eastern margin of northeast Brazil. Positions of the continent-ocean boundary (COB) along both margins are based on Karner \& Driscoll (1999) and Gomes (2005).

between the South and Equatorial Atlantic. The Pernambuco Plateau was formed prior to the inflexion of the rift axis caused by the formation of $E Z$ region, which led the rift evolution along the BP border. Northward, beyond the PESZ, the continental plat- form between João Pessoa and Natal represented the last link to be broken between Brazil and Africa (Rand \& Mabesoone, 1982).

It was proposed that the central region of the BP formed by the ZTN acted as a giant accommodation zone (Matos, 1992), 
which most likely caused the rift axis offset (Lima Filho \& Barbosa, 2010). Barbosa et al. (2008) also suggested that rifting forces began to break the BP nucleus (as indicated by the CaririPotiguar depression trend, and the Recôncavo-Tucano-Jatobá aborted continental rift), but as the process failed, the rift axis was offset to the east, and separated the BP border from the African plate. The authors also suggested that the eastern border of the BP, formed by the Paraíba and Natal Platform Basins (Figs. 1 to 4), remained a structural high, undergoing only minor stretching and thinning. The authors suggested that the most likely cause for this resistance to rifting was the thickness and nature (rheology) of the BP's central portion at the time of the event.

Previous analyses of regional 2D seismic data from this region showed that the basement in the coastal and marginal sections is shallow and forms a low-gradient ramp towards the shelf break (Barbosa \& Lima Filho, 2006; Lima Filho \& Barbosa, 2010). The proximal platform region exhibits normal faults, which caused the formation of narrow and shallow grabens. The seismic interpretation of the basement position has led some authors to estimate that the sedimentary cover over the platform ranges in thickness from 500-800 m (proximal zone) to $1500 \mathrm{~m}$ (distal zone to shelf break) (Fainstein \& Milliman, 1979; Barbosa et al., 2007; Lima Filho \& Barbosa, 2010). The platform in the study region is mainly dominated by carbonate ramps, most likely formed during the Upper Cretaceous (Beurlen, 1967; Barbosa et al., 2006, 2007). Along the coastal zone, deposits older than Turonian have not been found (Barbosa \& Lima Filho, 2006; Barbosa et al., 2007). However, there is a lack of biostratigraphic studies for the older siliciclastic succession in those basins. Evidence suggests that the rifting period for those basins finished after the Aptian, contrary to what was observed for other marginal basins along the Brazilian southeastern margin. Matos (1999) proposed that the rift along the eastern portion of the BP occurred during the Late Aptian and Albian, which is corroborated by the age of the rifting for the conjugate African basins, Rio Muni and Douala (Meyers et al., 1996; Turner et al., 2008). Córdoba et al. (2007) proposed that the rifting process along the eastern portion of the northeastern Brazilian margin, which led to the formation of the Pernambuco and Paraíba Basins, extended to the Upper Albian. Barbosa et al. (2014) presented evidence from the onshore region of the Pernambuco Basin, which points to an extension of the rifting process until the Middle Albian.

The transition from the continental to the oceanic domain is still not well defined for the eastern portion of BP (Fainstein \& Milliman, 1979; Lima Filho \& Barbosa, 2010). The location of the continent-ocean boundary $(\mathrm{COB})$ in this region was defined by a number of authors, mainly based in the analysis of regional geophysical data (Meyers et al., 1996; Karner \& Driscoll, 1999; Gomes, 2005; Blaich et al., 2008; Aslanian et al., 2009), although there is considerable debate about this matter. Fainstein \& Milliman (1979) suggested that the COB was relatively close to the platform-slope boundary in our study region. Lima Filho \& Barbosa (2010) proposed that the COB is positioned approximately $130 \mathrm{~km}$ from the coastline in the northern region of the EZ. A determination of the extent of continental crust and a better definition of the occurrence and age of rift-related deposits in the study area are important for two reasons: (1) a better comprehension of the evolution of this region during the rifting process and (2) the need for a better understanding of the area's petroleum potential.

The objective of this study was to determine the continentocean transition across the Paraíba Basin Platform (the southern part of the EZ), based on the analysis of two seismic sections that cross the region between the continent and the oceanic domain, and regional geophysical data acquired by potential methods. The results allowed us to determine the extent of thinned continental crust, which corresponds to the ocean-continent transition (OCT), and to acquire new information about the structural framework of the continental margin in the study region.

\section{Geological Setting}

The study area is located in the easternmost portion of the BP in northeast Brazil (Almeida et al., 1981), where it comprises the broken continental margin that was formed during the South Atlantic rift event (Fig. 1). The BP comprises the west-central part of a Brasiliano-Pan African tectonic collage that formed as a consequence of the late Neoproterozoic assembly of West Gondwana (Santos \& Medeiros, 1999; Van Schmus et al., 2003; Santos et al., 2010; Araujo et al., 2013). Most of the province consists of Paleoproterozoic to Archean basement blocks with Neoproterozoic metasedimentary and metavolcanic sequences forming major fold belts, pierced by voluminous granitic magmatism (Brito Neves et al., 2000; Van Schmus et al., 2003; Neves et al., 2012). The eastern part of the BP can be divided into three major tectonic domains: the Rio Grande do Norte domain (RN Domain), which is positioned to the north of the PASZ; a central domain, named here the ZTN, which is located between the PASZ and the PESZ (Fig. 1); and a southern domain located south of the PESZ, which was named here PE-AL Massif (Fig. 1). During separation of the South American and African plates, the Paraíba and Natal Platform marginal basins, which form the EZ, were implanted over the continental termination of the ZTN and part of the RN Domain (Figs. 1 to 4). 
The maximum depth reached by the sole stratigraphic well drilled in the study area (on Itamaracá Island in the Paraíba Basin) was $390 \mathrm{~m}$ (Barbosa et al., 2007), which represents the deepest basement position along the coastal region of the EZ. Information obtained from other wells (mainly drilled for hydrogeological purposes) along the coastal zone of the EZ, between the cities of Recife and Natal (Fig. 2), shows that the basement depth varies from 100 to $250 \mathrm{~m}$ along the Paraíba Basin, and from 80 to $200 \mathrm{~m}$ along the Natal Platform (Barbosa \& Lima Filho, 2006; Barbosa et al., 2006, 2007). The stratigraphic column of the Paraíba Basin is composed of sandstones, siltstones, and shales of the Beberibe Formation (Santonian-Campanian); carbonate-rich sandstones, sandy limestones, phosphatic siltstones, and dolomites of the Itamaracá Formation (Neo-Campanian to Eo-Maastrichtian); limestones, marly limestones, and marls of the Gramame Formation (Maastrichtian); marls, marly limestones, and sandy limestones of the Lower Maria Farinha Formation (Danian); and reef deposits of the Upper Maria Farinha Formation (Eocene?) (Barbosa \& Lima Filho, 2006; Barbosa et al., 2006, 2007). The stratigraphic sequence of the Natal Platform is less known. It is composed of sandy limestones and limestones in the basal portion (Turonian?-Campanian), and limestones, carbonate-rich sandstones, and dolostones in the upper portion (Maastrichtian) (Lana \& Roesner, 1999; Barbosa \& Lima Filho, 2006; Barbosa et al., 2007). The compartmentalization of the basins in the coastal zone was controlled by Precambrian shear zones and basement highs, mainly trending E-W and NE-SW. Transfer faults, trending N-S and NW-SE, are related to the rifting process and caused the formation of shallow grabens (Lima Filho, 1998; Bezerra et al., 2014).

\section{MATERIALS AND METHODS}

Data from the TOPEX/POSEIDON satellite project were used to construct a gridded $0.01^{\circ} \times 0.01^{\circ}$ free-air gravity anomaly field, and a topographic-bathymetric relief model. A gridded $0.03^{\circ} \times$ $0.03^{\circ}$ magnetic anomaly field model was produced using data from the EMAG2 Project, which integrates CHAMP satellite data, as well as aerial and marine surveys. From those gridded regional data, the following maps were produced: a digital elevation terrain (DET) (Fig. 2A); a free-air gravity anomaly map (FAA) (Fig. 2B); a Bouguer anomaly map (Fig. 3A); and a total magnetic intensity map (TMI) (Fig. 4A). The magnetic data were processed to obtain an analytic signal amplitude map (ASA) (Fig. 3B). Finally, a deep isostatic compensation map (DIC) was generated (Fig. 4B), based on the application of the Airy-Heiskanen isostatic compensation model to the DET.
Two multi-channel seismic-reflection surveys (time migrated sections), L1 and L2, were interpreted to assess the subsurface structure of the studied margin (Fig. 1). Line 1, obtained from the LEPLAC Program (Brazilian Navy Ministry), represents a long and deep profile (11 s two-way travel time (TWT)), located in the transition between the Pernambuco Plateau domain and the Paraíba Basin Platform (Fig. 5). This section does not run across the platform, but extends along the transition to the oceanic basin. Line 2, which covers the platform, starts approximately $5 \mathrm{~km}$ from the coastline line, but it is not deep enough (7 s TWT) to show the basement top in the continental transition region towards the oceanic basin (Fig. 6). To better understand the crustal transition from the shallow platform through transitional continental crust to the deep oceanic domain, both seismic sections were used in a complimentary way (Figs. 5 and 6).

Using features interpreted in the seismic data, two $2 \mathrm{D}$ geophysical profiles were modeled with the objective of differentiating continental and oceanic crustal domains (Fig. 5). The 2D profiles were extracted from FAA data along both seismic sections (Figs. 5 and 6). The density values used for the modeling of the geophysical profiles were estimated based on studies that considered heterogeneities in the transitions between different crustal domains (Wilson et al., 2003; Dupré et al., 2011).

The interpretation of the maps produced during this study was aided by the information provided by the modeled $2 \mathrm{D}$ profiles (crustal thickness and structures) (Figs. 2 to 6). Analyses of the resulting data are mainly qualitative, and were guided by the findings of recent studies regarding the evolution of the Atlantic Margin (Gomes et al., 2000; Watts, 2001; Wilson et al., 2003; Gomes, 2005; Blaich et al., 2008, 2010; Aslanian et al., 2009; Winterbourne et al., 2009; Dupré et al., 2011).

\section{RESULTS}

Three different domains were defined in the geophysical maps shown below: Sector A - continental crust (preserved); Sector B - transitional (thinned continental); and Sector $\mathrm{C}$ - oceanic crust. These domains represent the main variations observed in the map data along the crustal transition, which were interpreted to represent the different crustal domains. The maps chosen to illustrate the main differences between these domains were the FAA, DET, DIC, and ASA maps (Figs. 2, 3, and 4).

\section{Sector A (Preserved Continental Crust)}

Sector $A$ is bounded by the coastline to the west and by a yellow dotted line to the east (Figs. 2, 3, and 4). It is characterized by small $W$ to $E$ variations of the basement topography in the plat- 
form region. The DET map suggests a decrease of bathymetric values from -20 to $-400 \mathrm{~m}$, passing to the platform break (Fig. 2A). In the FAA map, this zone shows values ranging from 72 to $-25 \mathrm{mGal}$, which was interpreted as the first sign of thinning of the continental crust (Fig. 2B). The Bouguer map shows a variation of values between 170 and $260 \mathrm{mGal}$, which highlights the relatively flat profile of this platform (Fig. 3A). The ASA map shows variations between 3.5 to $2.0 \mathrm{nT} \mathrm{km}{ }^{-1}$, which is evidence for little influence of shallow magnetic bodies (Fig. 3B). The TMI map shows large anomalies trending NE-SW and E-W, with values ranging from -65 to $70 \mathrm{nT}$, which are most likely caused by deep crustal magnetic sources that cross the BP and the boundary of the continental margin (Fig. 4A). In the DIC map, which represents the depth of the crust-mantle boundary (Moho), Moho depth ranges from 27 to $28 \mathrm{~km}$, which was interpreted as preserved continental crust, with minor stretching and thinning (Fig. 4B).

The interpretation of the seismic basement, based on Line 2, shows a depth variation in the platform from $\sim 1.0$ to $\sim 1.8 \mathrm{~s}$ near the shelf border (Fig. 6). Converting the surveys from time (s) to depth (m) using a simple velocity model, allows us to infer that the thickness of the sedimentary cover varies from $0.8 \mathrm{~km}$ in the most proximal region to approximately $2.5 \mathrm{~km}$ near the shelf break (Fig. 6). From the coastline, this sector presents about 50$60 \mathrm{~km}$ wide at the Paraíba Basin, and about 35-40 km in the Natal Platform region.

\section{Sector B (Continental Transitional Crust)}

Sector B is bounded by a dotted yellow line (limit of preserved continental crust) to the west and a dotted black line, representing the COB, to the east (Figs. 2, 3, and 4). This sector is characterized by a strong variation in bathymetry, which ranges from about $-500 \mathrm{~m}$, to about $-4000 \mathrm{~m}$ in the DET map (Fig. 2A), indicating the presence of an abrupt continental shelf break and a depth increase towards the oceanic basin. In the FAA map, values across this sector range from -20 to $-60 \mathrm{mGal}$, which is not related to a gravimetric depression, as could be expected for the deep portion of a marginal basin (Fig. 2B). This strong decrease is most likely related to an abrupt break at the border of the platform in the direction of the slope escarpment. Negative anomalies are stronger in the region that forms the transition between the Pernambuco Plateau and the Paraíba Basin, immediately north of the PESZ. The Bouguer map also shows stronger variations ranging from 260 to $360 \mathrm{mGal}$, which were correlated to the rise of the Moho along the transitional zone (Fig. 3A). In the ASA map, this region shows a more complex variation of anomalies, with negative val- ues in the northern portion of the Paraíba Basin ranging from 6 to $1 \mathrm{nT} \mathrm{km}{ }^{-1}$, and a more abrupt transition from low to high values in the region of the Natal Platform from 3 to $17 \mathrm{nT} \mathrm{km}^{-1}$, where it seems that the oceanic crust is closer, and the anomalies are controlled by volcanic intrusions and seamounts (Fig. 3B). The TMI map shows strong anomalies trending E-W to NE-SW, perpendicular to the coastline, with positive values ranging from 30 to $90 \mathrm{nT}$ and negative values of -30 to $-80 \mathrm{nT}$, north of the PESZ (Fig. 4A). The anomaly that crosses the BP seems to terminate at the limit of thinned continental crust in the Natal Platform area. This anomaly is linked to the PASZ in the BP, and its termination can be used to determine the limit of the continental crust domain. The DIC map shows a variation linked to the rapid rise of the crust-mantle boundary, from a depth of $20 \mathrm{~km}$ (yellow dotted line) to $\sim 10.5 \mathrm{~km}$ depth (black dotted line in Fig. 4B). While investigating the location of the $\mathrm{COB}$ in the study region, we discovered a series of seamounts that had formed east of the COB, most likely related to large intrusions that developed along fractures zones in contact with the COB (black arrows in the DIC map).

The interpretation of the basement in this sector was carried out using seismic Line 1 (Fig. 5), because Line 2 did not reach the basement. However, is important to consider that Line 1 is positioned in the transition between the Pernambuco Plateau and the Paraíba Basin and that the basement in this region is most likely deeper than in the Paraíba Basin. In Line 1, the transitional zone extends for about $70 \mathrm{~km}$ beyond the shelf break, and basement depth varies from approximately 4.0 to $8.0 \mathrm{~s}$ (TWT), in the direction of the $\mathrm{COB}$. The maximum thickness of the sedimentary column in the small basin formed at the base of the slope (Gomes et al., 2000), is estimated to be about $\sim 2.5 \mathrm{~s}$ (TWT). The rift itself is narrow and represents a faulted and tilted sequence over thinned crust in the transitional zone (Fig. 5). However, the precise characteristics and age of these deposits remains unclear (Lima Filho \& Barbosa, 2010). Synthetic rotated faults gradually changed from subvertical to inclined as crustal thinning increased due continued extension. At the end of the transitional zone appears to be a section of thinned block, with rotated synthetic and antithetic faults. The geophysical signals indicate that this region contains abundant intrusions and associated pyroclastics most likely contributed to the sedimentary cover. We propose that this section represents a proto-oceanic crustal block. A possible cause for the formation of this feature could be the rapid thinning of the continental crust in this region, which was isolated and heavily intruded during oceanic crust formation. Some of the structures observed in this "proto-oceanic crust" domain suggest that it experienced some late-stage deformation involv- 
ing transpression (folded reflectors, pop-up geometry, and basin inversion). Blaich et al. (2010) proposed the existence of protooceanic crust in the Almada Basin, in northeastern Brazil. According to these authors, the cause for the formation of proto-oceanic crust was a fast ascension of the lower crust and consequent emplacement of the continental mantle, which may have caused a density increase. Wilson et al. (2003) proposed the existence of proto-oceanic crust in the Rio Muni Basin, West Africa, due the oblique opening process that affected that margin. The Rio Muni and Douala Basins represent the African equivalent of the Pernambuco and Paraíba Basins (Lima Filho \& Barbosa, 2010).

From Line 2 it is clear that the shelf break is even more abrupt in this sector and was controlled by subvertical rotated faults (Fig. 6). To the north, along the Natal Platform, the shelf break is so abrupt that the slope virtually becomes a vertical escarpment (Lima Filho \& Barbosa, 2010). In both lines, the seismic facies observed for the slope region indicate the presence of rift- and post-rift-deformed deposits, affected by the transport of material across the escarped slope, which transition to less deformed post-rift deposits covering the transitional and oceanic crust. The transport of material from the platform to the basin across the slope created a large bypass zone. As there are no wells in the offshore region, our interpretation of the rift and post-rift sequences are tentative.

Our conclusion is that Sector B was mostly influenced by crustal thinning and weakening. Variations observed in crustal thickness along this transitional sector were most likely caused by the fast ascension of the lower crust in response to rifting, which also caused the variations in the nature of the crust observed in the geophysical profiles (Wilson et al., 2003; Dupré et al., 2011) (Figs. 5 and 6). We did not see clear evidence for seaward-dipping reflectors (SDRs) within the transitional zone.

As shown on the maps and in the seismic sections, the COB is located approximately $100 \mathrm{~km}$ from the coastline in the region of the Paraíba Basin and approximately 60-80 km in the Natal Platform region (Figs. 2 to 6 ), with transitional crust forming a narrow strip between the two plateaus (Pernambuco and Touros).

\section{Sector C (Oceanic Crust)}

In Sector $\mathrm{C}$, the DET map shows bathymetric values typical for a deep ocean basin, ranging from -4000 to more than $-5000 \mathrm{~m}$ (Fig. 2A). Starting east of the proposed COB position, the FAA map shows a different pattern (Fig. 2B), with values increasing from -80 to $10 \mathrm{mGal}$, and peaks ranging from 19 to $70 \mathrm{mGal}$ observed on the seamounts. These higher values are clearly related to the oceanic crust domain. Negative anomaly zones within this domain could be caused by anomalous thinning of the oceanic crust along complex fracture zones. The Bouguer map shows values ranging from 370 to $500 \mathrm{mGal}$, which clearly indicate a shallower Moho and a signature typical of oceanic crust (Fig. 3A). The ASA map also shows a pattern typical for oceanic crust, with aligned pairs of positive and negative anomalies (trending $\mathrm{N}-\mathrm{S}$ or NW-SE), associated with the formation of oceanic crust wedges (seafloor spreading) and bounded by E-W-aligned large fracture zones to east of the proposed COB position (black dotted line). The ASA values in this region range from 1 to $18 \mathrm{nT} \mathrm{km}^{-1}$ (Fig. 3B). The TMI map shows that large anomalies trending $\mathrm{E}-$ $W$ in the Borborema Province end in the proposed COB region, corroborating that this location is the limit of the continental crust domain. On the other hand, east of the COB, large E-W anomalies in the oceanic crust show the influence of these BP structures on the formation of large transform faults and fracture zones. The pattern formed by N-S to NW-SE trending pairs of negative and positive anomalies east of the COB region, seems to be related to the formation of oceanic crust. The TMI values in this sector vary from -80 to $60 \mathrm{nT}$ (Fig. 4A). In the DIC map, Sector C shows depth values ranging from 12 to $9 \mathrm{~km}$, compatible with the depth of the Moho below oceanic crust (Fig. 4B). In regions where seamounts are present, the depth values vary from 14 to $17 \mathrm{~km}$, which could be caused by magmatic roots accreted at the base of the oceanic crust. We observed that the oceanic crust region east of the Paraíba Basin and Natal Platform was "thickened" due to the presence of seamounts related to terminations of fracture zones (Fig. 4B). A similar phenomenon occurs southeast of the Pernambuco Plateau, where a series of seamounts, implanted over the oceanic crust, create an apparent crustal thickening. Both regions are marked by the light blue lines in Figure 4B.

In seismic Line 1, Sector $C$ represents the oceanic crust domain, which is characterized by reflectors that mark the top of the oceanic basement. Seismic facies are dominated by parallel reflectors caused by post-rift/drift sequences. In the COB region, a volcano formed and was buried by what appear to be postCretaceous deposits. In addition, large seamounts, covered by sedimentary deposits are visible and clearly associated with the anomalies observed in the magnetic maps. A large number of subvertical faults were interpreted within the oceanic crust, which probably represent transfer faults that accommodated deformation of the oceanic crust. The Moho in this sector was tentatively interpreted to be at about $10 \mathrm{~s}$ (TWT). In Line 2, which did reach the basement, reflectors within the post-rift/drift sedimentary section show similar features as observed in Line 1, mainly dominated by a parallel configuration. 


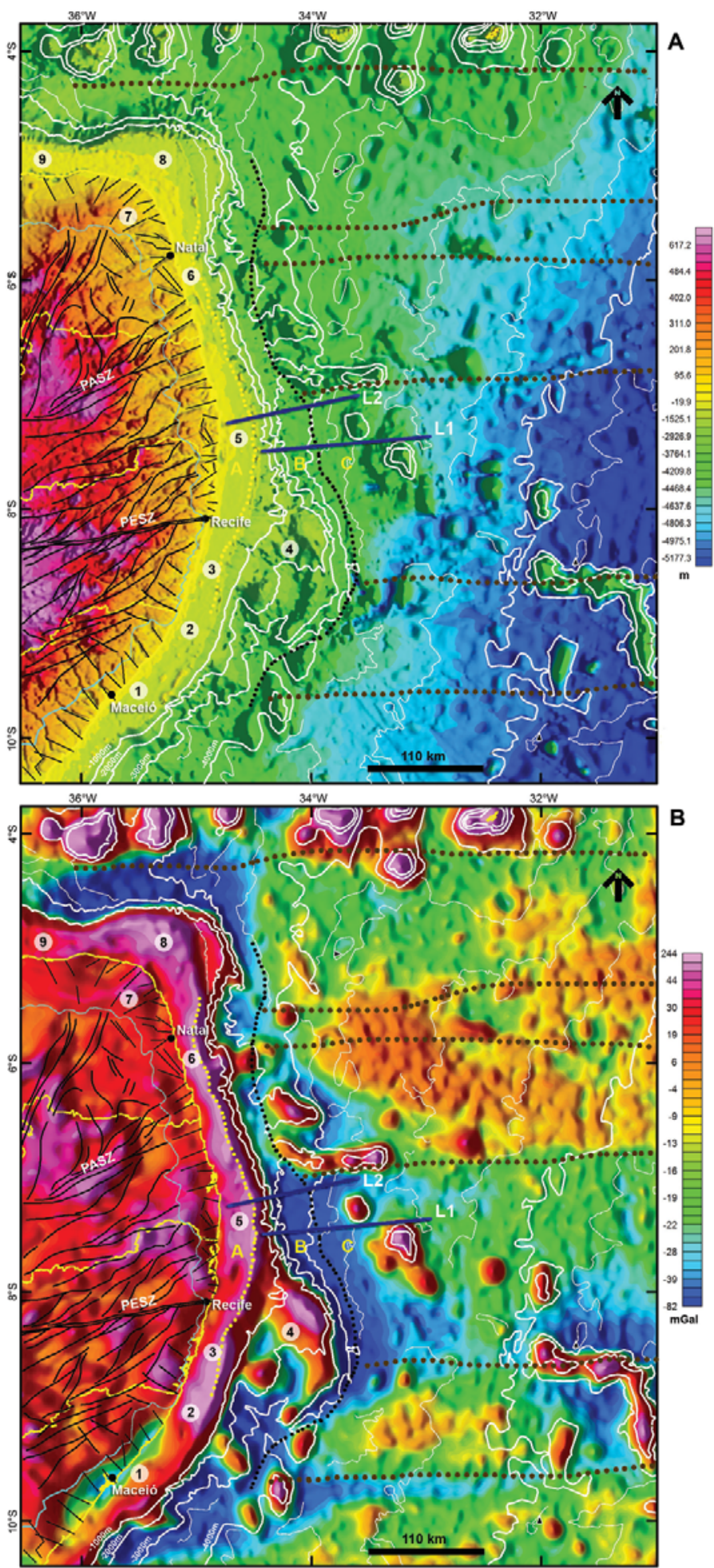

Figure 2 - A) Digital Elevation Terrain map (DET); B) Free-air Gravimetric Anomaly map (FAA). Main faults and shear zones in the Borborema Province are represented by black lines. The interpreted crustal sectors (continental, transitional, and oceanic) are indicated by the letters A, B, and C. Yellow dotted line marks the limit of the continental crust, black dotted line marks the COB position. Bathymetry is represented by white lines. The location of the 2D seismic lines discussed in the text are shown with blue lines (L1 and L2). Main fracture zones are indicated by brown dotted lines. 1 - Alagoas Basin; 2 - Maragogi High; 3 - Pernambuco Basin; 4 - Pernambuco Plateau; 5 - Paraíba Basin; 6 - Natal Plattorm Basin; 7 - Touros High; 8 - Touros Plateau; 9 - Potiguar Basin. 


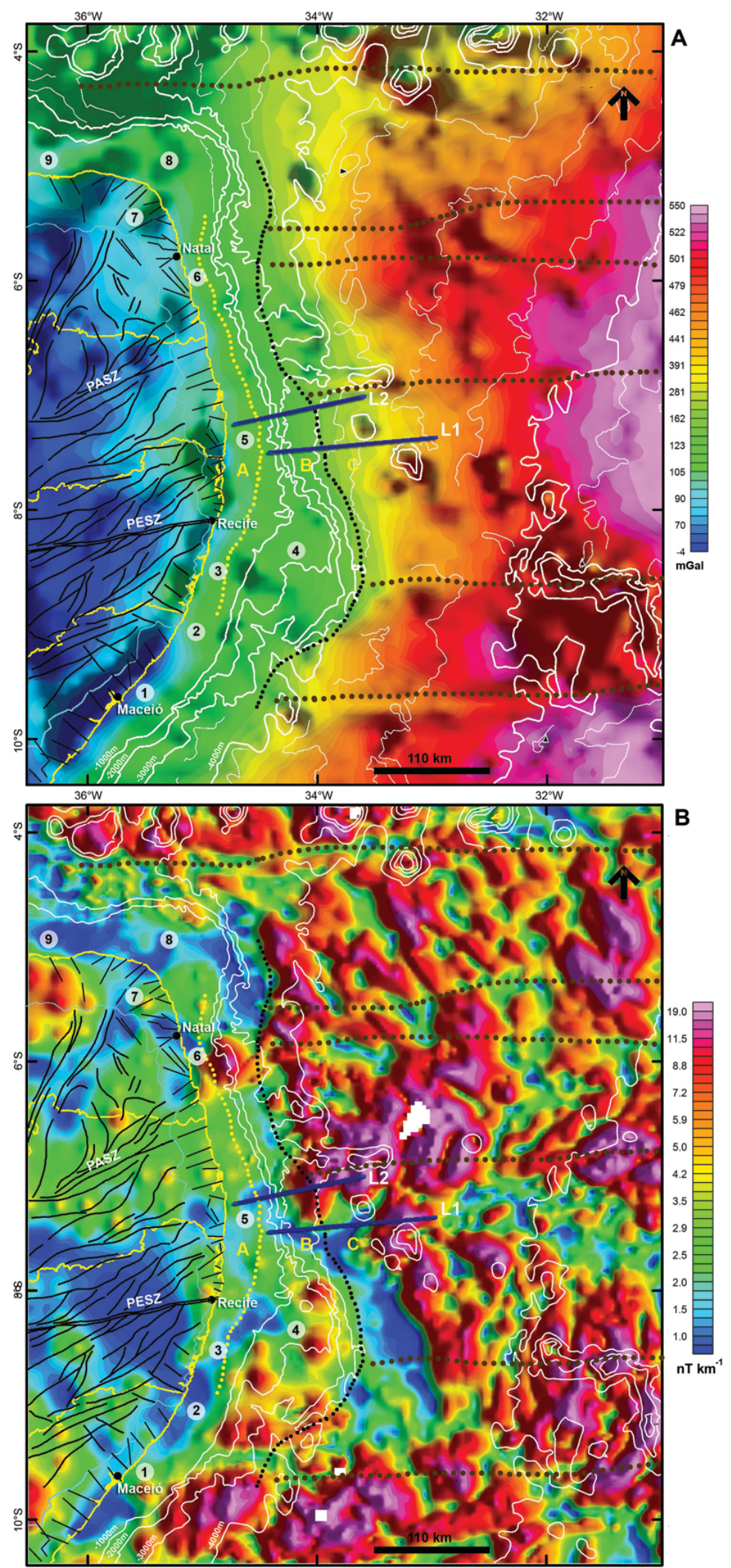

Figure 3 -A) Bouguer anomaly map; B) Analytical Signal Amplitude map (ASA). Symbols are the same as described in Figure 2. 

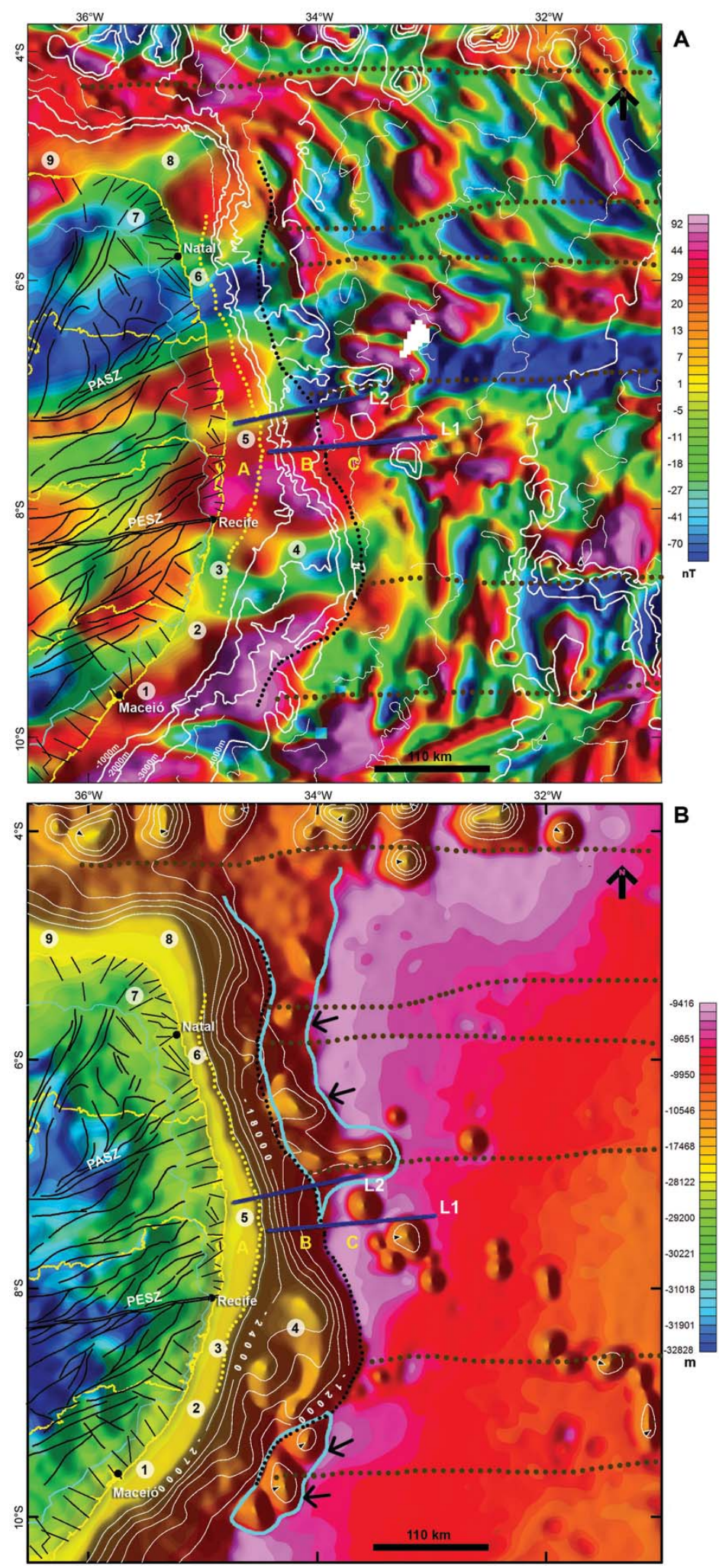

Figure 4 - A) Total Magnetic Intensity map (TMI); B) Deep Isostatic Compensation map (DIC). Symbols are the same described in Figure 2. The light blue lines mark areas of oceanic crust thickened by seamounts, related to fracture zones (black arrows). 


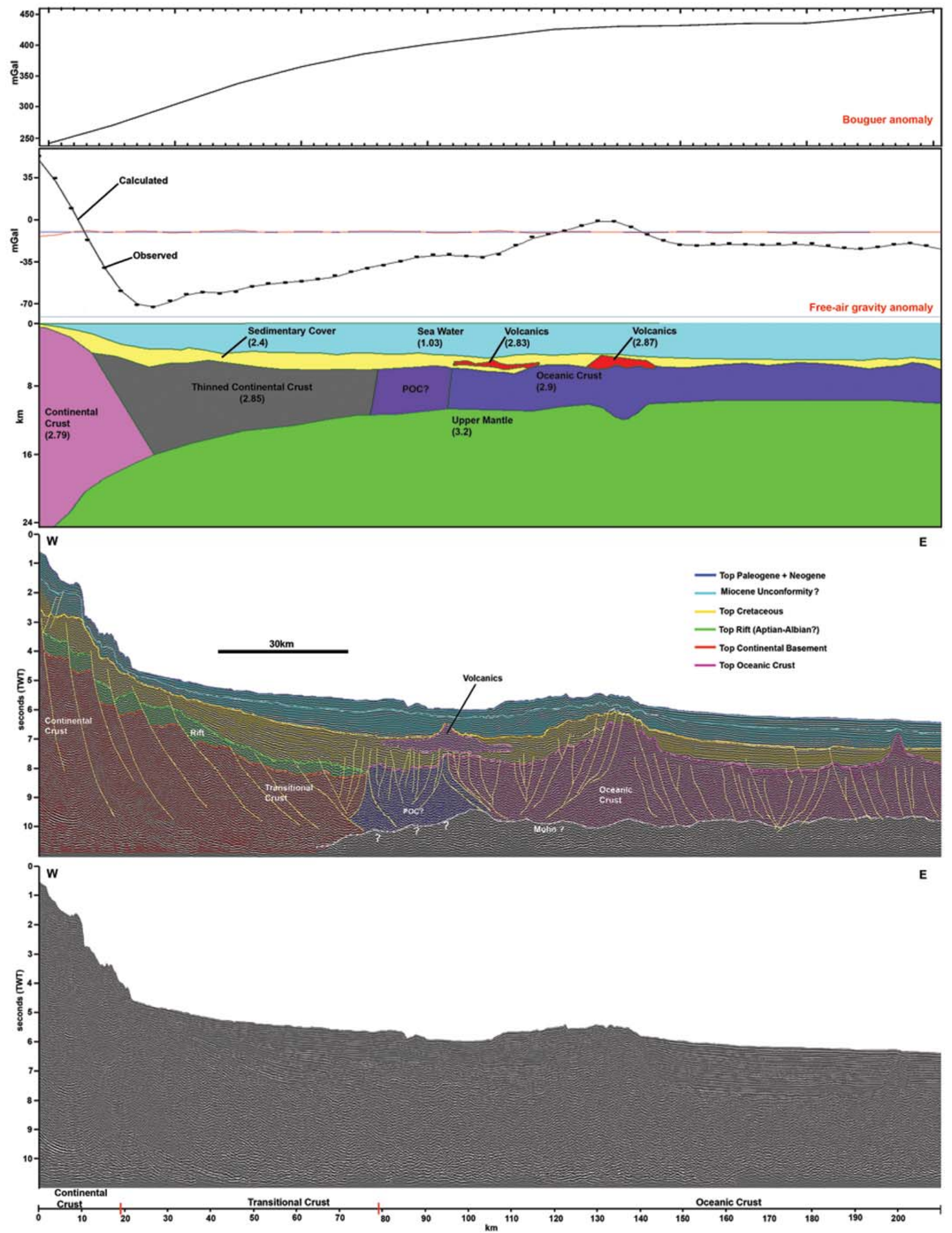

Figure 5 - Integrated geophysical profile. From top to bottom: Bouguer anomaly profile; Free-air gravity anomaly; geological model; interpreted seismic 2D section (L1); non-interpreted seismic section. Stratigraphic horizons were proposed based on previous studies by Barbosa et al. (2008) and Lima Filho \& Barbosa (2010). 

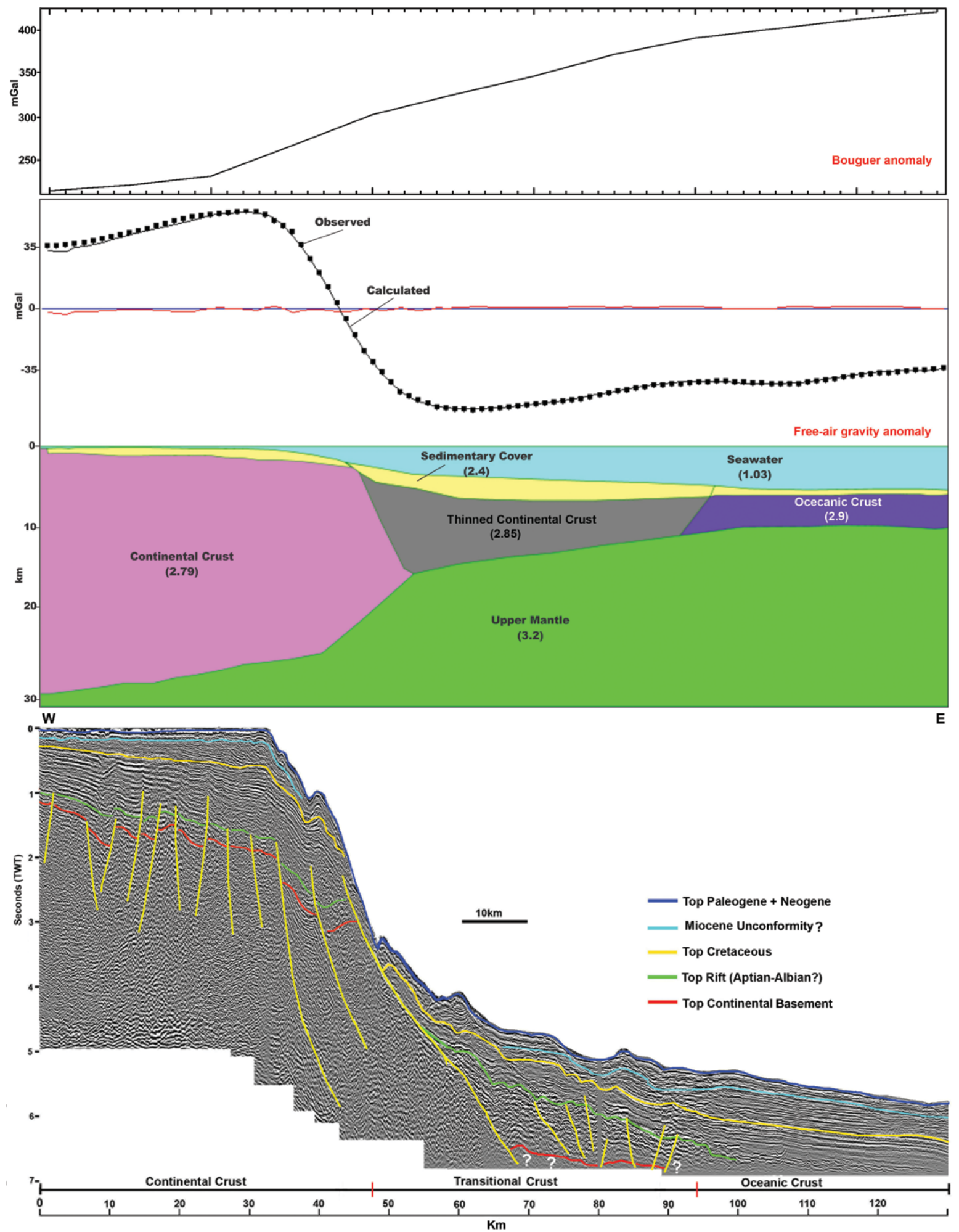

Figure 6 - Integrated geophysical profile. From top to bottom: Bouguer profile; Free-air gravity anomaly; geological model; interpreted seismic 2D section (L2); non-interpreted seismic section. Stratigraphic horizons were proposed based on previous studies by Barbosa et al. (2008) and Lima Filho \& Barbosa (2010). 


\section{DISCUSSION}

Despite the limitation of available data in the study area, the geophysical and seismic data analyzed allow a qualitative evaluation of the continental-oceanic crust transition in the region of the Paraíba Platform. The modeled gravity profiles, constrained by the interpretation of two 2D seismic sections, including one deep survey from the LEPLAC Program, allow a more complete interpretation of the main features of the marginal basins in this part of the Brazilian Margin. The isostatic compensation map (DIC) is important for estimating crustal thickness (Fig. 4B) and for inferring the position of the COB. The geological/gravity model produced, which considered the main differences in the nature of the crust along the transition from the continental to the oceanic domain and which was guided by the interpretation of the seismic data, represents a realistic model for the crust and upper mantle of this region.

The Paraíba Basin exhibits strong asymmetries when compared to its African counterpart and different physical characteristics of each margin (thickness and rheological response to the rifting) played an important role in this apparent misfit. If compared with the conjugate margin (Niger Delta (Benue Through) and Douala Basin), the region that encompasses the Paraíba Basin and the Natal Platform Basin (the EZ) shows interesting differences: tectonic style; thickness of sedimentary cover, as previously discussed by Brito Neves et al. (2002); and different amounts of stretching of the transitional crust. Bonatti (1996) argued that the "equatorial belt" between Africa and South America represents a cold and thick lithospheric zone, which created a locked zone for rift propagation. To overcome this obstacle, the rift generated a large E-W shear zone. A similar hypothesis suggests that the nucleus of the BP, largely formed by the ZTN and bounded by two large shear zones, acted as a giant accommodation zone (Mattos, 1992; 1999), blocking rift propagation along the interior of northeastern Brazil (Figs. 1, 2, and 3). Another hypothesis is that the propagating rift was stopped by a thick and cold region of the plate, which forms the nucleus of the BP, as proposed by Lima Filho \& Barbosa (2010). In fact, the ZTN is characterized by igneous bodies that intruded along the large shear zones (Santos \& Medeiros, 1999) during the Brasiliano Event, such as the CaruaruArcoverde Batholith (Neves \& Mariano, 1999) linked to the PESZ, and the Teixeira Batholith in the PASZ. Certainly, the ZTN played an important role in this process, remaining the thicker portion of the BP as observed in the isostatic compensation map (Fig. 4B). Crustal thickness, inferred from Moho depth, reaches more than $33 \mathrm{~km}$ along the ZTN, following its E-W trend. New investigations of the BP framework, using deep seismic data and geophysical transects, produced information that corroborates the importance of the ZTN and its boundaries, which are formed by shear zones, mainly by the PASZ (De Castro et al., 2011; Osako et al., 2011). The ZTN crustal thickness estimated using our isostatic compensation model seems to match the geophysical models. Limited amounts of fusion and thinning of the ZTN may have occurred during uplift, which also would have affected the BP. However, there are no estimates for the extent of these processes. Crustal thickness of the ZTN does not appear to be representative for what existed during the time of rifting because deep crustal features could have been modified by the rifting process (Osako et al., 2011) and by late lifting of the BP nucleus (Oliveira, 2008; Pavão et al., 2013). The abrupt thinning of the continental crust and the limited extent of transitional crust, suggest only a small amount of stretching and thinning during the rift process. Moreover, the lack of clear evidence for well-developed SDRs indicates that this margin has stronger similarities to non-volcanic margins. Blaich et al. (2010) discussed the remarkable asymmetry in lithospheric extension between the Camamu-Almada and Gabon conjugate margins. The authors suggested a model involving depthdependent extension mechanisms, which could also be the case for the Paraíba and Natal Platform Basins. However, more data are needed to gain a better understanding of this eastern portion of northeastern Brazil.

With regard to economic issues, we can consider two main implications for the petroleum potential of the region: first, the delay in the rift process implies that source rock formation may have been negatively affected; second, the relatively thin sediment cover, both onshore and offshore, reduces the possibility of a productive petroleum system. However, the transition region between the Pernambuco Plateau and the Paraíba Basin seems to be more promising than the narrower transitional zone of the Natal Platform.

\section{CONCLUSIONS}

Geophysical data presented in this paper reveal that the continental margin of the Paraíba Basin is characterized by a narrow platform with an abrupt shelf break, an escarped slope, and a narrow zone of stretched transitional crust. It is possible that this region suffered less thinning than neighboring areas such as the Pernambuco and Sergipe-Alagoas Basins, which contain more strongly stretched transitional crust with a thick sedimentary cover. The continent-ocean boundary in the region of the Paraíba Basin is located at a distance of approximately $100 \mathrm{~km}$ from the coastline. The modeled 2D geological/gravity profile was divided in three crustal domains: the continental sector, marked by positive 
gravity anomalies and an abrupt platform break; the transitional sector (weakened continental crust + transitional crust), which exhibits a gravity minimum; and a third sector, where an increasing eastward gravity gradient marks the beginning of the oceanic crust. The three sectors are characterized by variations in estimated crustal thickness (inferred from the deep isostatic map): crustal thickness in Sector 1 varies from 27 to $28 \mathrm{~km}$ and represents preserved continental crust; thickness in Sector 2 varies from 10.5 to $20 \mathrm{~km}$ and represents transitional crust; Sector 3 represents oceanic crust with thickness values of approximately $10 \mathrm{~km}$. The poor expression of a rift sequence in the platform region, which is completely absent in the proximal areas, could be the result of late and fast rifting processes in this region. The amount and distribution of rift deposits in the deepest parts of the basin is still unclear because of a lack of offshore wells. The sedimentary cover over the platform and the extent of transitional crust seems to be less pronounced than in neighboring basins, which restricts the petroleum potential of the basins that form the EZ, and points to a remarkable asymmetry compared to the African conjugate margin.

\section{ACKNOWLEDGEMENTS}

We are grateful to the Human Resources Program, PRH-26/UFPE, of the Agência Nacional do Petróleo, Gás e Biocombustíveis (ANP); to the LEPLAC Program (Banco Nacional de Dados Oceanográficos, Marinha do Brasil), which provided seismic data for this research; to the Laboratory of Sedimentary Geology (LAGESE/UFPE); to the Seismic Stratigraphy Laboratory (SISMOS/LAGESE/UFPE); to the reviewers who provided important suggestions to the manuscript; to Sinochem Petróleo Brasil Ltda.; and to IHS KINGDOM for providing the seismic interpretation software licenses to LAGESE/UFPE.

\section{REFERENCES}

ALMEIDA FFM, HASUI Y, BRITO NEVES BB \& FUCK RA. 1981. Brazilian structural provinces: an introduction. Earth-Science Reviews, 17: 1-29.

ARAUJO CEG, WEINBERG RF \& CORDANI UG. 2013. Extruding the Borborema Province (NE-Brazil): a two-stage Neoproterozoic collision process. Terra Nova, 26: 157-168.

ASLANIAN D, MOULIN M, OLIVET J-L, UNTERNEHR P, MATIAS L, BACHE F, RABINEAU M, NOUZÉ H, KLINGELHEOFERF, CONTRUCCII \& LABAILS C. 2009. Brazilian and African passive margins of the Central Segment of the South Atlantic Ocean: Kinematic constraints. Tectonophysics, 468: 98-112.

BARBOSA JA \& LIMA FILHO MF. 2006. Aspectos estruturais e estratigráficos da faixa costeira Recife-Natal: observações em dados de poços. Boletim de Geociências da Petrobras, 14(2): 287-306.

BARBOSA JA, VIANA MSS \& NEUMANN VH. 2006. Paleoambientes e icnofácies da seqüência carbonática (Cretáceo e Paleogeno) da Bacia da Paraíba, NE do Brasil. Revista Brasileira de Geociências, 36(3): 449464.

BARBOSA JA, NEUMANN VH, LIMA FILHO M, SOUZA EM \& MORAES MA. 2007. Estratigrafia da faixa costeira Recife-Natal (Bacia da Paraíba e Plataforma de Natal), NE Brasil. Estudos Geológicos, 17(2): 3-30.

BARBOSA JA, LIMA FILHO M, NEUMANN VH, JESUS NETO JC \& ARAÚJJO JAA. 2008. Potencial exploratório das bacias da Paraíba e da Plataforma de Natal. In: Rio Oil \& Gas Conference. Rio de Janeiro, Boletim de Trabalhos Técnicos. Rio de Janeiro, 2008, CD-ROM (IBP_1746).

BARBOSA JA, MAIA MF, LIMA FILHO M, MAGALHÃES JR \& CORREIA 0. 2014. Seismic stratigraphy of the onshore portion of Pernambuco Basin: evidence of break-up during Middle Albian for the South Atlantic Rift in Northeast Brazil. In: AAPG Annual Exhibition and Convention, Houston. Search and Discovery Article \#30324.

BEURLEN K. 1967. Paleontologia da faixa costeira Recife-João Pessoa. Boletim de Geologia, Universidade de São Paulo, 16: 73-79.

BEZERRA FHR, ROSSETTI DF, OLIVEIRA RG, MEDEIROS WE, BRITO NEVES BB, BALSAMO F, NOGUEIRA FCC, DANTAS EL, ANDRADES FILHO C \& GÓES AM. 2014. Neotectonic reactivations of shear zones and implications for faulting style and geometry in the continental margin of NE Brazil. Tectonophysics, 614: 78-90.

BLAICH OA, TSIKALAS F \& FALEIDE JI. 2008. Northeastern Brazilian margin: regional tectonic evolution based on integrated analysis of seismic reflection and potential field data and modelling. Tectonophysics, 458(1/4): 51-67.

BLAICH OA, FALEIDE JI, TSIKALAS F, LILLETVEIT R, CHIOSSI D, BROCKBANK P \& COBBOLD P. 2010. Structural architecture and nature of the continent-ocean transitional domain at the Camamu and Almada Basins (NE Brazil) within a conjugate margin setting. In: VINING BA \& PICKERING SC (Eds.). Petroleum Geology: From Mature Basins to New Frontiers - Proceedings of the 7th Petroleum Geology Conference, 867-883

BLAICH OA, FALEIDE JI \& TSIKALAS F. 2011. Crustal breakup and continent-ocean transition at South Atlantic conjugate margins. Journal of Geophysical Research, 116: 1-38.

BONATTI E. 1996. Anomalous opening of the Equatorial Atlantic due to an equatorial mantle thermal minimum. Earth and Planetary Science Letters, 143(1/4): 147-160.

BRITO NEVES BB, SANTOS EJ \& VAN SCHMUS WR. 2000. Tectonic history of the Borborema Province, northeastern Brazil. In: International Geological Congress, 31., Proceedings, Rio de Janeiro, Brazil, 151-182. 
BRITO NEVES BB, VAN SCHMUS WR \& FETTERA. 2002. North-western Africa-North-eastern Brazil. Major tectonic links and correlation problems. Journal of African Earth Sciences, 34(3): 275-278.

CÓRDOBA VC, JARDIM DE SÁ EF, SOUSA DC \& ANTUNES AF. 2007. Bacia de Pernambuco-Paraíba. Boletim de Geociências da Petrobras, 15(2): 391-403.

DE CASTRO DL, OSAKO LS, SOARES JEP, FUCK RA \& LIMA VAG. 2011. Gravity and Deep Seismic Transects across the Precambrian Borborema Province, NE Brazil. In: SEG Annual Meeting, 81., San Antonio. Expanded Abstracts, San Antonio: SEG, 2011, 897-911.

DUPRÉ S, CLOETINGH S \& BERTOTTI G. 2011. Structure of the Gabon Margin from integrated seismic reflection and gravity data. Tectonophysics, 506(1/4): 31-45.

FAINSTEIN R \& MILLIMAN JD. 1979. Structure and origin of three continental-margin plateaus, Northeastern Brazil. AAPG Bulletin, 63(2): 218-238.

GOMES P0. 2005. Tectonismo, vulcanismo, sedimentação e processos erosivos no segment nordeste da margem continental brasileira. Unpublished Doctorate Thesis, Universidade Estadual do Rio de Janeiro, Rio de Janeiro, 2005. $183 \mathrm{pp}$.

GOMES PO, GOMES BS, PALMA JJC, JINNO K \& SOUZA JM. 2000. Ocean-continent transition and tectonic framework of the oceanic crust at the continental margin of Northeast Brazil: results of LEPLAC Project. American Geophysical Union, Monography Series, 15: 261-291.

GUIRAUD R \& MAURIN J. 1992. Early Cretaceous rifts of Western and Central Africa: an overview. Tectonophysics, 213(1/2): 153-168.

KARNER GD \& DRISCOLL NW. 1999. Tectonic and stratigraphic development of the West African and eastern Brazilian margins: insights from quantitative basin modelling. In: CAMERON NR, BATE RH \& CLURE VS (Eds.). The oil and gas habitats of the South Atlantic. Special Publication, 153, GSL, 11-40.

LANA MCC \& ROESNER EH. 1999. Palinologia do Cretáceo Superior marinho subaflorante na região de Natal, RN. Anais da Academia Brasileira de Ciências, 7(1): 149-150.

LENTINI MR, FRASER SI, SUMMER HS \& DAVIES RJ. 2010. Geodynamics of the Central South Atlantic conjugate margins: implications for hydrocarbon potential. Petroleum Geoscience, 16: 217-229.

LIMA FILHO MF. 1998. Análise Estrutural e Estratigráfica da Bacia Pernambuco. Unpublished Doctorate Thesis, Universidade de São Paulo, $1986.139 \mathrm{pp}$.

LIMA FILHO MF \& BARBOSA JA. 2010. The peculiar tectonostratigraphic evolution of the eastern margin of Northeast Brazil, and its African Counterpart. In: Central and North Atlantic Conjugate Margins Conference, 2., 2010, Lisbon. Proceedings Book, Lisbon, 8: 304-308.
MATOS RMD. 1992. The northeast Brazilian rift system. Tectonics, 11(4): 766-791.

MATOS RMD. 1999. History of the northeast Brazilian rift system: kinematic implications for the break-up between Brazil and West Africa. In: CAMERON NR, BATE RH \& CLURE VS (Eds.). The oil and gas habitats of the South Atlantic. Special Publication, 153, GSL, 55-73.

MEYERS JB, ROSENDAHL BR, GROSCHEL-BECKERH, AUSTIN JR JA \& RONA PA. 1996. Deep penetrating MCS imaging of the rift-to-drift transition, offshore Douala and North Gabon basins, West Africa. Marine and Petroleum Geology, 13(7): 791-835.

NEVES SP \& MARIANO G. 1999. Assessing the tectonic significance of a large-scale transcurrent shear zone system: the Pernambuco lineament, northeastern Brazil. Journal of Structural Geology, 21(10): 1369-1383.

NEVES SP, MONIÉP, BRUGUIER 0 \& SILVA JMR. 2012. Geochronological, thermochronological and thermobarometric constraints on deformation, magmatism, and thermal regimes in eastern Borborema Province (NE Brazil). Journal of South American Earth Sciences, 38: 129-146.

OLIVEIRARG. 2008. Arcabouço geofísico, isostasia e causas do magmatismo Cenozóico da Província da Borborema e de sua margem continental (NE do Brasil). Unpublished Doctorate Thesis, Universidade Federal do Rio Grande do Norte, Natal, 2008. 411 pp.

OSAKO LS, DE CASTRO DL, FUCK RA, CASTRO NA \& PITOMBEIRA JPA. 2011. Contribuição de uma seção gravimétrica transversal ao estudo da estruturação litosférica na porção setentrional da Província Borborema, NE do Brasil. Brazilian Journal of Geophysics, 29(2): 309-329.

PAVÃO CG, FRANÇA GS, BIANCHI M, ALMEIDA T \& VON HUELSEN MG. 2013. Upper-lower thickness of the Borborema Province, NE Brazil, using Receiver Function. Journal of South American Earth Sciences, 42: 242-249.

RAND HM \& MABESOONE JM. 1982. Northeastern Brazil and the final separation of South America and Africa. Palaeogeography, Palaeoclimatology, Palaeoecology, 38: 163-183.

REYMENT RA \& DINGLE RV. 1986. Paleogeography of Africa during the Cretaceous period. Palaeogeography, Palaeoclimatology, Palaeoecology, 59: $93-116$.

SANDWELL DT \& SMITH WHF. 2009. Global marine gravity from retracked Geosat and ERS-1 altimetry: Ridge Segmentation versus spreading rate. Journal of Geophysical Research, 114: 1-18.

SANTOS EJ \& MEDEIROS VC. 1999. Constraints from granitic plutonism on Proterozoic crustal growth of the Transverse Zone, Borborema Province, NE, Brazil. Revista Brasileira de Geociências, 29(1): 73-84.

SANTOS EJ, VAN SCHMUS WR, KOZUCH M \& BRITO NEVES BB. 2010. The Cariris Velhos tectonic event in Northeast Brazil. Journal of South American Earth Sciences, 29: 61-76. 
SMITH WHF \& SANDWELL DT. 1997. Global Sea floor Topography from Satellite Altimetry and Ship Depth Soundings. Science, 277: 1956-1962.

TURNER JP. 1995. Gravity-Driven Structures and Rift Basin Evolution: Rio Muni Basin, Offshore Equatorial West Africa. 1995. AAPG Bulletin, 79: 1138-1158.

TURNER JP, GREEN PF, HOLFORD SP \& LAWRENCE SR. 2008. Thermal history of the Rio Muni (West Africa)-NE Brazil margins during continental breakup. Earth and Planetary Science Letters, 270: 354-367.

VAN SCHMUS WR, BRITO NEVES BB, WILLIAMS IS, HACKSPACHER AH, FETTER AH, DANTAS EL \& BABINSKI M. 2003. The Seridó Group of NE Brazil, a late Neoproterozoic pre- to syn-collisional basin in West Gondwana: insights from SHRIMP U-Pb detrital zircon ages and Sm-Nd crustal residence (TDM) ages. Precambrian Research, 127: 287-327.
VAUCHEZ A, NEVES SP, CABY R, CORSINI M, EGYDIO-SILVA M, ARTHAUD MH \& AMARO V. 1995. The Borborema shear zone system, NE Brazil. Journal of South American Earth Sciences, 8: 247-266.

WATTS AB. 2001. Gravity anomalies, flexure and crustal structure at the Mozambique rifted margin. Marine and Petroleum Geology, 18: $445-455$.

WILSON PG, TURNER JP \& WESTBROOK GK. 2003. Structural architecture of the ocean-continent boundary at an oblique transform margin through deep-imaging seismic interpretation and gravity modelling: Equatorial Guinea, West Africa. Tectonophysics, 374: 19-40.

WINTERBOURNE J, CROSBY A \& WHITE N. 2009. Depth, age, and dynamic topography of oceanic lithosphere beneath heavily sedimented Atlantic margins. Earth and Planetary Science Letters, 287: 137-151.

\section{NOTES ABOUT THE AUTHORS}

José Ricardo Magalhães. Geologist, graduate from Universidade Federal de Pernambuco (UFPE) in 2013, and is developing master course at the PPGEOC-UFPE, with focus on geophysics of potential field methods and seismic stratigraphy applied to sedimentary basin analysis.

José Antonio Barbosa. Professor at the Department of Geology, Universidade Federal de Pernambuco, and research interests are seismic stratigraphy and basin analysis, with experience in sedimentary basins of NE Brazil.

Jefferson Tavares Cruz Oliveira. Physicist with a master degree in Geophysics from PPGEOC-UFPE in 2013, and is developing doctorate course with thermal properties of the continental crust of Pernambuco Plateau. Research interests are potential field methods and seismic data processing.

Mário Ferreira de Lima Filho. Professor at the Department of Geology, Universidade Federal de Pernambuco, with experience in tectonic evolution of sedimentary basins of NE Brazil. 